\title{
Relationships between nutrition, puberty and mammary development in cattle
}

\author{
BY KRIS SEJRSEN \\ National Institute of Animal Science, Foulum, DK-8830 Tjele, Denmark
}

\begin{abstract}
Production of colostrum and milk in sufficient amounts is essential for survival of the young in most mammals. Thus, lactation is an integral part of the reproductive cycle and, in line with its role in reproduction, mammary development occurs in distinct phases related to reproductive development during fetal life, puberty, pregnancy, and lactation. The main developments, quantitatively as well as qualitatively, occur during late pregnancy, when mammary ducts develop into lobulo-alveolar tissue with differentiated cells capable of producing milk with all its components. It is the number of mammary cells in the mammary glands that largely determines the lactation potential of the mother.

In cattle, lactation has an added significance in view of the important role of cow's milk in human nutrition. Mammary development in cattle largely follows the same pattern as in other mammals, but mammary cell growth is believed to end at parturition. Therefore the milk yield potential of cows is determined, to a large extent, by the growth of the mammary glands around puberty and during pregnancy. The extent of mammary gland development during puberty is much less pronounced than during pregnancy, but it has become clear that mammary development in this period is critical for the future milk yield potential of heifers (Sejrsen, 1978; Foldager \& Sejrsen, 1987; Johnsson, 1988; Troccon \& Petit, 1989; Waldo et al. 1989). One of the important factors influencing pubertal mammary growth is nutrition. Given this background it is the objective of the present paper to provide an overview of the relationships between nutrition, puberty and mammary development in heifers.
\end{abstract}

\section{PUBERTAL MAMMARY DEVELOPMENT}

The basic structures of the mammary glands are formed in fetal life, but the epithelial tissue is still rudimentary at birth. There are a few mammary duct cells present adjacent to the gland cistern, but there are no alveoli. In contrast, the non-epithelial tissues, i.e. the stroma and the circulatory system, are almost fully developed at birth; so is the outer shape of the glands. In the first few months after birth the glands grow isometrically at the same rate as the rest of the body; only the non-epithelial tissues grow in this period.

At 2-3 months of age, well in advance of the onset of puberty, the glands start to grow at a faster rate than the rest of the body. The growth becomes allometric (Sinha \& Tucker, 1969). In this phase there is rapid growth of the fat pad, and of the ducts that branch into it. Alveoli are still unformed. The ducts need the fat pad for their growth (Faulkin \& De Ome, 1960), and in some species ductular growth may be limited by the size of the fat pad. This is unlikely to be the case in heifers, since the tissue with the branching ducts, the parenchyma, only constitutes about one-third of the total gland at this stage of development (Sejrsen \& Foldager, 1992). In contrast to the situation in rodents, the ducts in heifers always seem to be surrounded by connective tissue (see Akers, 1990). 
At the end of the allometric growth phase the mammary glands of heifers weigh about $2-3 \mathrm{~kg}$, of which only about $0 \cdot 5-1 \mathrm{~kg}$ is parenchyma. The parenchyma usually contains between $10-20 \%$ epithelium, $40-50 \%$ connective tissue and $30-40 \%$ fat cells (Sejrsen et al. 1982). In comparison, lactating mammary glands can weigh as much as $25 \mathrm{~kg}$ (Foldager \& Sejrsen, 1991), and lactating parenchyma consists of 40-50\% epithelial cells (ducts and alveoli), 15-20\% lumen, about $40 \%$ connective tissue and almost no fat cells (Harrison et al. 1983).

\section{MEASUREMENT OF MAMMARY GROWTH}

Since the parenchyma constitutes only a small part of the total mammary gland in heifers, it is very difficult, if not impossible, to get a reliable estimate of the amount of mammary parenchyma in the live animal. Palpation scores and biopsies often yield misleading results, because the relative amounts of parenchymal and extraparenchymal tissue can be changed by environmental factors, such as the level of feeding (Sorenson et al. 1964; Sejrsen et al. 1982; Stelwagen \& Grieve, 1989). Reliable estimation of the amount of parenchyma therefore requires that the animals are slaughtered and the parenchyma separated from the stroma by dissection, or alternatively that the animals are subjected to computer tomography-scanning (Sørensen et al. 1987). These measures are more reliable if complemented by estimation of DNA content and/or histological evaluation to obtain a measure of the composition of the parenchyma (Tucker, 1987).

\section{ONSET OF PUBERTY}

Most studies suggest that the return to isometric mammary growth coincides with onset of puberty or occurs shortly thereafter (Sinha \& Tucker, 1969; Pritchard et al. 1972; Sejrsen et al. 1982). Therefore variation in age and live weight at onset of puberty is an important factor for mammary growth.

Onset of puberty usually occurs at 9-11 months of age and at an average body weight of $250-280 \mathrm{~kg}$ in heifers of the large dairy breeds. However, both age and body weight at onset of puberty vary widely within as well as between breeds. In our experiments with Friesian and Red Danish heifers we have observed that heifers can reach puberty as early as 5-6 months and as late as 18-20 months of age (Foldager et al. 1988). The variation in live weight at onset of puberty was also large (from 150 to $400 \mathrm{~kg}$ ), but fewer than $5 \%$ of the heifers reached puberty before $200 \mathrm{~kg}$ live weight, and fewer than $10 \%$ of the heifers had first oestrus after $300 \mathrm{~kg}$ live weight.

There is no doubt that nutrition is a major factor for the variation in age at onset of puberty (for reviews, see Moran et al. 1989; Robinson, 1990; Schillo et al. 1992). The impact of nutrition is illustrated by the results of one of our experiments, in which wide variation in daily growth rate was achieved by varying the feeding level (Foldager et al. 1988). Average age at first oestrus decreased from 16.6 to 8.4 months as the growth rate was increased from 400 to $850 \mathrm{~g} / \mathrm{d}$. In contrast, average live weight at first oestrus was unaffected by feeding level. These results clearly confirm that reproductive development in cattle, as in humans (Frisch, 1984), is more closely related to body development than to chronological age (see Moran et al. 1989 and Schillo et al. 1992). Consequently, it is very important to consider this relationship when interpreting data concerning the influence of nutrition on mammary growth. Comparison of mammary growth at the same 
age will in many cases include a significant confounding effect of differences in mammary development due to differing live weights between nutritional treatment groups.

\section{THE OVARIES AND PUBERTAL MAMMARY DEVELOPMENT}

Puberty in females is the culmination of a long gradual maturation process, that is initiated before birth and continues throughout the prepubertal and peripubertal period (Kinder et al. 1987). Most components of the endocrine system required for stimulation of the onset of puberty are functional long before puberty occurs, but onset of puberty is inhibited by negative feedback of oestradiol on the secretion of luteinizing hormone (LH), resulting in release of LH in low-frequency pulses (Kinder et al. 1987; Schillo et al. 1992).

The allometric growth phase of the mammary glands in heifers is closely linked to gradual maturation of the ovaries. Ovariectomy within the first week of life abolishes mammary growth in heifers, but surprisingly not in lambs (Wallace, 1953; Johnsson, 1984). Ovariectomy of heifers at 2.5 months of age also reduces mammary growth. In two of eight heifers ovariectomized at 2.5 months of age, mammary parenchyma was completely absent (Purup et al. 1993c). In the remaining six heifers the amount of mammary parenchyma was reduced to $10-15 \%$ of that in intact control heifers. The two heifers with no mammary parenchyma weighed $60 \mathrm{~kg}$ at ovariectomy, while the others weighed $80 \mathrm{~kg}$. The difference in weight could account for the difference in response, and support the idea that a relationship between 'physiological' stage of development (body weight) and mammary development exists.

Most evidence suggests that the effect of the ovaries on mammary development is mediated by oestrogen. First, oestrogen and stilboestrol replacement can restore the allometric growth of the mammary glands in ovariectomized rodents (Cowie, 1949) and in heifers (Wallace, 1953) respectively. Second, recent findings by Woodward et al. (1993) indicate that proliferation of mammary duct cells is significantly enhanced by oestradiol in vivo. Third, an effect of oestradiol on mammary cell growth in vitro, although difficult to demonstrate, has been observed (S. J. Winder \& I. A. Forsyth, unpublished results) in sheep explants. Purup et al. (1993a) have also seen a dose-related stimulatory effect of oestradiol on in vitro thymidine incorporation in explants from prepubertal heifers. In heifers the plasma level of oestrogen was significantly reduced by ovariectomy (Purup et al. 1993c). However, the levels of oestradiol were very low, and the difference in circulating levels between intact and ovariectomized heifers was very small $(0.41 v .0 .31 \mathrm{pg} / \mathrm{ml} ; P<0.05)$. Therefore, it is difficult to imagine that the almost complete block of mammary growth can be due to this small difference in plasma oestradiol, unless somehow there is a significant difference in its biological activity. The biological activity of oestradiol is limited by its binding to a plasma globulin, and reproductive development seems to be related to the level of free circulating oestrogen (see Kirkwood et al. 1987). It is possible, therefore, that the difference in mammary growth is due to a lower proportion of free oestradiol in the ovariectomized animals. It is also possible that the difference in mammary growth following ovariectomy is due to changes in other ovarian secretions. Insulin-like growth factor 1 (IGF-1), for instance, is present in follicular fluid in large quantities (Spicer et al. 1991; S. Purup and K. Sejrsen, unpublished results). However, the plasma level of IGF-1 is not affected by ovariectomy (Purup et al. 1993c). 
The effect of ovariectomy on mammary growth could also be indirect via changed secretion of hormones (or growth factors) from other tissues. Waksman et al. (1991) have demonstrated that extracts from the pituitary, the kidney and the uterus produce stimulatory effects on mammary cell proliferation. It is possible, therefore, that hormones secreted by the ovary might affect mammary growth indirectly by influencing the secretion of hormones (or growth factors) by other tissues. The secretion of LH, for instance, is elevated by ovariectomy (Kinder et al. 1987). On the basis of these findings we have conducted preliminary studies of the possible effect of LH on mammary cell proliferation (S. Purup \& K. Sejrsen, unpublished results). Although no clear picture has emerged, it appears that the effect of LH is dependent on the level of IGF-1 in the incubation medium. Prolactin has previously been suggested as a possible mediator of oestrogen effects on mammary growth, because prolactin secretion is regulated by oestrogen. However, this hypothesis has not been confirmed (Akers, 1990).

Tucker (1981) suggested that the return of mammary tissue to isometric growth at puberty might be caused by the asynchronous secretion of oestrogen and progesterone that starts at this time. Recent observations (K. Sejrsen, D. Petitclerc, D. J. Prendeville and W. J. Enright, unpublished results) suggest that the signal to terminate the allometric growth phase is either independent of ovarian secretions or appears before onset of puberty. We found that the amount of mammary parenchyma at 20 months of age was the same in heifers reaching puberty at normal age, and in heifers that had puberty permanently delayed by immunization against gonadotrophin-releasing hormone at 8 months of age.

\section{NUTRITION AND PUBERTAL MAMMARY DEVELOPMENT}

The most important nutritional factor influencing mammary growth is, without doubt, daily energy intake (feeding level). The effect of feeding level on mammary growth in virgin heifers has been investigated in many experiments (Sejrsen et al. 1982; Harrison et al. 1983; Petitclerc et al. 1984; Valentine et al. 1987; Petitclerc \& Bailey, 1991). The results demonstrate that feeding levels resulting in daily gains above $600-700 \mathrm{~g}$ by heifers of large dairy breeds have a negative influence on growth of the mammary parenchyma, and suggest that this negative effect is limited to the pubertal period of mammary growth. The mammary gland seems to be 'sensitive' to the negative effect of high feeding level as early as 3 months of age (P. E. Mantysaari, V. Toivonen, K. L. Ingvartsen \& K. Sejrsen, unpublished results). The same conclusion is evident in experiments investigating the effect of feeding level during rearing on subsequent milk potential of heifers (Foldager \& Sejrsen, 1991; Peri et al. 1993).

In several experiments, differences in feeding level were achieved by concentrating the energy composition of the diet. In this context, Little \& Kay (1979) observed that the effect of feed energy concentration could be a contributing factor to the observed effects. However, results from several other experiments indicate that mammary growth is unaffected by the energy concentration of the feed (Capuco et al. 1986; Waldo et al. 1988; Sejrsen \& Foldager, 1992).

In many experiments investigating the effect of feeding level it is not possible to separate the effects of energy and protein. While the specific effect of protein level alone has not been investigated, the effect of protein source has been studied. Results suggest that the effect of feeding level is independent of the protein source since there was no 
difference between animals given protein supplement as rapeseed meal or urea (P. E. Mantysaari, V. Toivonen, K. L. Ingvartsen \& K. Sejrsen, unpublished results).

Recent results obtained by McFadden et al. $(1990 a, b)$ indicate that mammary growth can be affected by specific components of the diet. They showed that lambs given protected polyunsaturated fat had increased mammary growth. Addition of polyunsaturated fat resulted in an increased number of growth hormone $(\mathrm{GH})$ and prolactin receptors in the liver tissue, indicating that the higher mammary growth could be due to increased level of IGF-1 in the blood.

\section{ENDOCRINE BASIS FOR THE EFFECT OF FEEDING LEVEL}

According to classical studies on regulation of mammary development, $\mathrm{GH}$ is required for normal growth of mammary ducts (Lyons et al. 1958; Cowie et al. 1966). Many investigations of the endocrine basis for the negative effect of high feeding level on mammary growth in heifers have focused on the possible role of $\mathrm{GH}$. The results have shown that the circulating level of $\mathrm{GH}$ is reduced at high feeding level (Sejrsen et al. 1983; Johnsson, 1988). Consequently, the level of GH is positively correlated with mammary growth (Sejrsen et al. 1983; Johnsson et al. 1985; Sejrsen \& Foldager, 1992). Furthermore, mammary growth is increased by exogenous growth hormone (Johnsson et al. 1986; Sejrsen et al. 1986; Sandles et al. 1987) indicating a cause and effect relationship between circulating level of $\mathrm{GH}$ and mammary growth. These results support the hypothesis that the effect of feeding level on pubertal mammary growth is mediated by reduced secretion of $\mathrm{GH}$.

In spite of its documented effect on pubertal mammary growth, the mechanism of action of GH is not clear. Although GH-receptor mRNA is present in mammary tissue from pubertal heifers (S. Purup, H. Jammes, J. Djiane \& K. Sejrsen, unpublished results), pregnant heifers (Hauser et al. 1990) and cows (Glimm et al. 1990), a direct effect of GH on the mammary gland of prepubertal heifers is questionable. First, it has not been possible to demonstrate $\mathrm{GH}$ binding to mammary tissue from prepubertal heifers (Purup et al. 1993b). Second, GH does not stimulate proliferation of mammary epithelial cells from prepubertal heifers in vitro (S. Purup \& K. Sejrsen, unpublished results). Most evidence suggests that $\mathrm{GH}$ acts indirectly on the mammary gland of prepubertal heifers via IGF-1. Secretion of IGF-1 is increased by GH administration (Purup et al. 1993c), IGF-1 binding sites are present in the mammary tissue (Purup et al. $1993 b$ ) and IGF-1 stimulates proliferation of mammary cells in vitro (Shamay et al. 1988; Purup et al. $1993 a$ ).

The fact that GH seems to act on the mammary gland of prepubertal heifers via IGF-1 argues against the conclusion that the effect of feeding level on lactation potential is mediated by GH. This is because the level of IGF-1 is increased and not decreased, as is $\mathrm{GH}$, by high feeding levels (Breier et al. 1988). This apparent paradox may be explained in different ways. The true cause and effect relationship between GH, IGF-1 and mammary growth may be modified by IGF-1 binding proteins and/or local IGF-1 production in the mammary gland. It is also possible that $\mathrm{GH}$, despite the cited evidence to the contrary, acts directly on the mammary gland. Local action in the mammary gland was observed in the classical studies with rodents (Lyons et al. 1958). This observation was confirmed recently by Kleinberg et al. (1990). Collier et al. (1993) also observed a 
stimulatory effect on mammary growth in cattle when GH was administered directly into the mammary gland via the streak canal during pregnancy.

We (S. Purup and K. Sejrsen, unpublished results) are attempting to ascertain the importance of IGF-1 for the biological effect of $\mathrm{GH}$ using in vitro techniques. In our initial experiments we found that the proliferation of pubertal mammary cells, as determined by thymidine incorporation in mammary explant DNA, was higher when explants were incubated with serum from GH-treated heifers than with serum from placebo-treated heifers. Our aim is to ascertain whether the effect of GH on mammary growth is mediated via IGF-1 or an unknown mediatory protein as suggested for lactation in rats (Flint et al. 1993).

A role for prolactin in the mediation of nutritional effects on mammary growth has been suggested, but no consistent relationship between prolactin and mammary growth has been demonstrated in several experiments with heifers and lambs (Sejrsen et al. 1983; Petitclerc et al. 1984; Johnsson et al. 1986; Sejrsen \& Foldager, 1992). Johnsson et al. (1986) observed that mammary growth in lambs was unaffected by treatment with CB154, a synthetic compound that blocks prolactin secretion.

A role for oestrogen cannot be ruled out, since the proportion of free oestrogen, and oestrogen metabolism, are influenced by degree of fatness. The biological activity of oestrogen is modulated by its metabolism (Kirkwood et al. 1987). However, the relevance of these changes in biological activity to the effect of feeding level on mammary growth has not been investigated.

\section{PUBERTAL MAMMARY DEVELOPMENT AND MILK PRODUCTION}

The importance of the pubertal period as a determinant of the milk yield potential of heifers is evident in a large number of experiments. Results show that a feeding level resulting in gains of more than $600-700 \mathrm{~g} / \mathrm{d}$ in heifers of large dairy breeds during growth between 100 and $300 \mathrm{~kg}$ live weight has a negative influence on the subsequent milk yield (see reviews by Foldager \& Sejrsen, 1987; Johnsson, 1988; Troccon \& Petit, 1989; Waldo et al. 1989). This period, which coincides with the pubertal phase of mammary development, therefore seems to be a critical period for the establishment of the milk yield potential of the heifers (Sejrsen, 1978). The critical importance of this period is clearly demonstrated in experiments published by Foldager \& Sejrsen (1991), Ingvartsen et al. (1988) and Peri et al. (1993) and in a large experiment involving about 300 heifers of three dairy breeds (J. Foldager, P. Madsen, J. Jensen \& B. B. Andersen, unpublished results).

Although the negative influence of feeding level on subsequent milk yield has been observed in many experiments, there are exceptions (e.g. Gardner et al. 1988; Waldo et al. 1988). Although the reason for the variation in responses observed in different experiments is not clear, there are several possible explanations. For instance, in some experiments the differences in feeding level were fairly small and several experiments started at a fairly high body weight. In some experiments the heifers were only subjected to the different treatments shortly before the heifers at high feeding level reached puberty. Moreover, the discrepancies may have been caused by large individual variations in growth rate due to the feeding regimen used. It is our observation (Foldager \& Sejrsen, 1991) that the negative influence of a high feeding level at one stage of the critical period cannot be compensated by lowering the feeding level in the 
following stage. This is true even if the overall average growth rate is satisfactory. Finally, it is likely that heifers of different genetic backgrounds may tolerate different levels of nutrition. The optimal growth rate is clearly different in Jersey (Ingvartsen et al. 1988) and Holstein (Foldager \& Sejrsen, 1991) heifers.

\section{SUMMARY}

The available studies concerning the relationships between nutrition, puberty and mammary development demonstrate the importance of pubertal mammary growth for the future development and ultimate milk-producing capacity of the mammary gland. A relationship between reproductive development and mammary development is also evident and mammary development at puberty is clearly influenced by the feeding level at that time. The role of specific nutrients has not been thoroughly investigated, but results suggest that specific fatty acids may be involved in the regulation of mammary growth. Mammary growth during puberty is affected by oestrogen and $\mathrm{GH}$, but their respective roles and mechanisms of action have not yet been clarified.

\section{REFERENCES}

Akers, R. M. (1990). Lactation physiology: a ruminant perspective. Protoplasma 159, 96-111.

Breier, B. H., Gallaher, B. W. \& Bass, J. J. (1988). Influence of nutritional status and oestradiol-17 $\beta$ on plasma growth hormone, insulin-like growth factor-I and -II and the response to exogenous growth hormone in young steers. Journal of Endocrinology 118, 243-250.

Capuco, A. V., Smith, J. J. \& Waldo, D. R. (1986). Influence of diet and prepubertal growth rate of Holstein heifers on mammary gland growth and concentration of prolactin and growth hormone in serum. Journal of Dairy Science 69, Suppl. 1, 202.

Collier, R. J., McGrath, M. F., Byatt, J. C. \& Zurfluh, L. L. (1993). Regulation of bovine mammary growth by peptide hormones: involvement of receptors, growth factors and binding proteins. Livestock Production Science 35, 21-34.

Cowie, A. T. (1949). The relative growth of the mammary gland in normal, gonadectomized and adrenalectomized rats. Journal of Endocrinology 6, 145-157.

Cowie, A. T., Tindal, J. S. \& Yokoyama, A. (1966). The induction of mammary growth in the hypophysectomized goat. Journal of Endocrinology 15, 185-195.

Faulkin, L. J. \& De Ome, K. B. (1960). Regulation of growth and spacing of gland elements in the mammary fat pad of the CH3 mouse. Journal of the National Cancer Institute 24, 953-969.

Flint, D. J., Tonner, E. \& Beattie, J. (1993). Growth hormone stimulates lactation in the rat independently of the insulin-like growth factors or their binding proteins. Abstr. Presented at Spring meeting of the Growth Factor Group of the British Endocrine Societies, Liverpool.

Foldager, J. \& Sejrsen, K. (1987). Mammary gland development and milk production in dairy cows in relation to feeding and hormone manipulation during rearing. In Cattle Production Research. Danish Status and Perspectives, pp. 102-116. Frederiksberg; Landhusholdningsselskabets Forlag.

Foldager, J. \& Sejrsen, K. (1991). Rearing intensity in dairy heifers and the effect on subsequent milk production. Report from the National Institute of Animal Science, no. 693. Tjele, Denmark: National Institute of Animal Science.

Foldager, J., Sejrsen, K. \& Sørensen, J. T. (1988). The effect of plane of nutrition on growth and feed utilization in RDM and SDM heifers - revision of energy requirements for growth. Report from the National Institute of Animal Science, no. 648. Tjele, Denmark: National Institute of Animal Science.

Frisch, R. E. (1984). Body fat, puberty and fertility. Biological Reviews 59, 161-188.

Gardner, R. W., Smith, L. W. \& Park, R. L. (1988). Feeding and management of dairy heifers for optimal lifetime productivity. Journal of Dairy Science 71, 996-999.

Glimm, D. R., Baracos, V. E. \& Kennelly, J. J. (1990). Molecular evidence for the presence of growth hormone receptors in the bovine mammary gland. Journal of Endocrinology 126, R5-R8. 
Harrison, R. D., Reynolds, J. P. \& Little, W. (1983). A quantitative analysis of mammary glands of dairy heifers reared at different rates of live weight gain. Journal of Dairy Research 50, 405-412.

Hauser, S. D., McGrath, M. F., Collier, R. J. \& Krivi, G. G. (1990). Cloning and in vivo expression of bovine growth hormone receptor mRNA. Molecular and Cellular Endocrinology 72, 187-200.

Ingvartsen, K. L., Foldager, J., Larsen, J. B. \& Østergaard, V. (1988). Growth and milk yield by Jersey cows reared at different planes of nutrition. Report from the National Institute of Animal Science no. 645. Tjele, Denmark: National Institute of Animal Science.

Johnsson, I. D. (1984). Nutritional and hormonal infiuences on prepubertal mammogenesis in sheep and rats. PhD Thesis, University of Reading.

Johnsson, I. D. (1988). The effect of pubertal nutrition on lactation performance by dairy cows. In: Nutrition and Lactation in the Dairy Cow, pp. 171-192 [P. C. Garnsworthy, editor]. London: Butterworth.

Johnsson, I. D., Hart, I. C., Simmonds, A. D. \& Morant, S. V. (1985). Pre-pubertal mammogenesis in the sheep. 2. The effect of level of nutrition on the plasma concentrations of growth hormone, insulin and prolactin at various ages in female lambs and their relationship with mammary development. Animal Production 41, 333-340.

Johnsson, I. D., Hart, I. C. \& Turvey, A. (1986). Pre-pubertal mammogenesis in the sheep. 3. The effect of restricted feeding or daily administration of bovine growth hormone and bromocriptine on mammary growth and morphology. Animal Production 42, 53-63.

Kinder, J. E., Day, M. L. \& Kittok, R. J. (1987). Endocrine regulation of puberty in cows and ewes. Journal of Reproduction and Fertility 34, Suppl., 167-186.

Kirkwood, R. N., Cummings, D. C. \& Aherne, F. X. (1987). Nutrition and puberty in the female. Proceedings of the Nutrition Society 46, 177-192.

Kleinberg, D. L., Ruan, W., Catanese, V., Newman, C. B. \& Feldman, M. (1990). Non-lactogenic effects of growth hormone on growth and insulin-like growth factor-I messenger ribonucleic acid of rat mammary gland. Endocrinology 126, 3274-3276.

Little, W. \& Kay, R. M. (1979). The effect of rapid rearing and early calving on subsequent performance of dairy heifers. Animal Production 29, 131-142.

Lyons, W. R., Li, C. H. \& Johnson, R. E. (1958). The hormonal control of mammary growth. Recent Progress in Hormone Research 14, 219-254.

McFadden, T. B.. Daniel, T. E. \& Akers, R. M. (1990a). Effects of plane of nutrition, growth hormone and unsaturated fat on mammary growth in prepubertal lambs. Journal of Animal Science 68, 3171-3179.

McFadden, T. B., Daniel, T. E. \& Akers, R. M. (1990b). Effects of plane of nutrition, growth hormone and unsaturated fat on growth hormone, insulin and prolactin receptors in prepubertal lambs. Journal of Animal Science 68, 3180-3189.

Moran, C., Quirke, J. F. \& Roche, J. F. (1989). Puberty in heifers: a review. Animal Reproduction Science 18, $167-182$.

Peri, I., Gertler, A., Bruckental, I. \& Barash, H. (1993). The effect of manipulation in energy allowance during the rearing period of heifers on hormone concentrations and milk production in first lactation cows. Journal of Dairy Science 76, 742-751.

Petitclerc, D. \& Bailey, D. R. C. (1991). Effects of genotype and plane of nutrition on mammary development of beef heifers. Journal of Animal Science 69, Suppl. 1, 324.

Petitclerc, D., Chapin, L. T. \& Tucker, H. A. (1984). Carcass composition and mammary development responses to photoperiod and plane of nutrition in Holstein heifers. Journal of Animal Science 58, 913-919.

Pritchard, D. E., Hafs, H. D., Tucker, H. A., Boyd, L. J., Purchas, R. W. \& Huber, J. T. (1972). Growth, mammary, reproductive and pituitary hormone characteristics of Holstein heifers fed extra grain and melengestrol acetate. Journal of Dairy Science 55, 995-1004.

Purup, S., Sejrsen, K. \& Akers, R. M. (1993a). Influence of estradiol on insulin-like growth factor I (IGF-I) stimulation of DNA synthesis in vitro in mammary gland explants from intact and ovariectomized prepubertal Holstein heifers. Livestock Production Science 35, 182

Purup, S., Sejrsen, K. \& Akers, R. M. (1993b). Influence of ovariectomy on the effect of bovine growth hormone treatment on mammary growth, serum hormones, and liver and mammary gland receptors in prepubertal Holstein heifers. Livestock Production Science 35, 182-183.

Purup, S., Sejrsen, K., Foldager, J. \& Akers, R. M. (1993c). Effect of exogenous bovine growth hormone and ovariectomy on prepubertal mammary growth, serum hormones, and in vitro proliferative response of mammary explants from Holstein heifers. Journal of Endocrinology 139, 19-26.

Robinson, J. J. (1990). Nutrition in the reproduction of farm animals. Nutrition Research Reviews 3, 253-276. 
Sandles, L. D., Peel, C. \& Temple-Smith, P. D. (1987). Mammary development and first lactation milk yields of identical twin heifers following prepubertal administration of bovine growth hormone. Animal Production 45, 349-357.

Schillo, K. K., Hall, J. B. \& Hileman, S. M. (1992). Effects of nutrition and season on the onset of puberty in the beef heifer. Journal of Animal Science 70, 3994-4005.

Sejrsen, K. (1978). Mammary gland development and milk yield in relation to growth rate in the rearing period in dairy and dual purpose heifers. Acta Agriculturae Scandinavica 28, 41-46.

Sejrsen, K. \& Foldager, J. (1992). Mammary growth and milk production capacity of replacement heifers in relation to diet energy concentration and plasma hormone levels. Acta Agriculturae Scandinavica 42, 99-105.

Sejrsen, K., Foldager, J., Sørensen, M. T., Akers, R. M. \& Bauman, D. E. (1986). Effect of exogenous bovine somatotropin on pubertal mammary development in heifers. Journal of Dairy Science 69, 1528-1538.

Sejrsen, K., Huber, J. T. \& Tucker, H. A. (1983). Influence of amount fed on hormone concentrations and their relationship to mammary growth in heifers. Journal of Diary Science 66, 845-855.

Sejrsen, K., Huber, J. T., Tucker, H. A. \& Akers, R. M. (1982). Influence of plane of nutrition on mammary development in pre- and postpubertal heifers. Journal of Dairy Science 65, 783-800.

Shamay, A., Cohen, N., Niwa, M. \& Gertler, A. (1988). Effect of insulin-like growth factor I on deoxyribonucleic acid synthesis and galactopoiesis in bovine undifferentiated and lactating mammary tissue in vitro. Endocrinology 123, 804-809.

Sinha, Y. N. \& Tucker, H. A. (1969). Mammary development and pituitary prolactin level of heifers from birth through puberty and during oestrus cycle. Journal of Dairy Science 52, 507-512.

Sorenson, A. M., Hansel, W., Hough, W. H., Armstrong, D. T., McEntee, K. \& Bratton, R. W. (1964). Causes and prevention of reproductive failures in dairy cattle. I. Influence of underfeeding and overfeeding on growth and development of Holstein heifers. Cornell University Agricultural Bulletin no. 936. Ithaca, N.Y.: Cornell University.

Sørensen, M. T., Sejrsen, K. \& Foldager, J. (1987). Estimation of pubertal mammary development in heifers by computer tomography. Journal of Dairy Science 70, 265-270.

Spicer, L. J., Enright, W. J., Murphy, M. G. \& Roche, J. F. (1991). Effect of dietary intake on concentrations of insulin-like growth factor-I in plasma and follicular fluid, and ovarian function in heifers. Domestic Animal Endocrinology 8, 431-437.

Stelwagen, K. \& Grieve, D. G. (1989). Effect of plane of nutrition on growth and mammary gland development in Holstein heifers. Journal of Dairy Science 73, 2333-2341.

Troccon, J. L. \& Petit, M. (1989). Criossance des genisses de renouvellement et performances ulterieures (Growth of replacement heifers and their subsequent milk production). INRA Productions Animales 2 , 55-64.

Tucker, H. A. (1981). Physiological control of mammary growth, lactogenesis and lactation. Journal of Dairy Science 64, 1403-1421.

Tucker, H. A. (1987). Quantitative estimates of mammary growth during various physiological states: a review. Journal of Dairy Science 70, 1958-1966.

Valentine, S. C., Dobos, R. C., Lewis, P. A., Bartsch, B. D. \& Wickes, R. B. (1987). Effect of live weight gain before or during pregnancy on mammary gland development and subsequent milk production of Australian Holstein-Friesian. Australian Journal of Experimental Agriculture 27, 195-204.

Waksman, M., Shamay, A. \& Gertler, A. (1991). Bovine pituitary, kidney, uterine and mammary gland extracts contain bovine mammary epithelium growth factors that synergise with IGF-I and fetal calf serum: indication for involvement of GTP-binding proteins. Domestic Animal Endocrinology 8, 271-280.

Waldo, D. R., Capuco, A. V. \& Rexroad, C. E. (1989). Replacement heifer growth rate affects milk producing ability. Feedstuffs 27, 15-17.

Waldo, D. R., Rexroad, C. E. \& Capuco, A. V. (1988). Effects of diet and daily gain as heifers on milk production of Holstein cattle. Journal of Dairy Science 71, Suppl. 1, 217.

Wallace, C. (1953). Observations on mammary development in calves and lambs. Journal of Agricultural Science 43, 413-421.

Woodward, T. L., Beal, W. E. \& Akers, R. M. (1993). Cell interactions in initiation of mammary epithelial proliferation by oestradiol and progesterone in prepubertal heifers. Journal of Endocrinology 136, $149-157$. 